\title{
The influence of religion on science: the case of the idea of predestination in biospeleology
}

\author{
Aldemaro Romero Jr. $¥$ \\ $\ddagger$ Baruch College, New York, United States of America
}

Corresponding author: Aldemaro Romero Jr. (aromerojr123@gmail.com)

\begin{abstract}
Evolution has always been considered a battleground between religion and science. Despite that perception, there are some indications that religious beliefs have influenced and continue to influence some current interpretations in evolutionary biology. To that end I present evidence on how pervasive the theological idea of predestination, which has been long discussed in the the Jewish, Christian and Muslim traditions, has influenced some of the elucidations of the nature of biological evolution. I will concentrate on the history of ideas about the evolution of cave organisms to epitomize the strong influence of religion on some evolutionary ideas as shown not only by some of the interpretations but also by the terminology still used today. I conclude that scientists need to understand the historical and philosophical framework of their research if they really want to claim that their work is really value-free.
\end{abstract}

This paper discusses the influence of religious thought on evolutionary thinking particularly regarding cave biology.

\section{Keywords}

predetermination, science and religion, biological evolution, biospeleology, cave biology, history of science 


\section{Introduction}

Part of the conventional wisdom in scientific circles dominated by reductionist views of research is that science is or can be both value-free and ahistorical. However, there has been mounting criticism to this position, i.e., that ideology has intruded and will continue to intrude into science (For a discussion on these issues see Kincaid et al. 2007).

The idea of predestination defined as the doctrine that contends that God predestines from eternity the salvation of certain souls, has been debated for a long time in theological circles (For earlier discussions on this issue see Weizsäcker (1859), Das Dogma von der göttlichen Vorherbestimmung im 9. Jahrhundert in Jahrbücher für deutsche Theologie; Dieckhoff (1883), Zur Lehre von der Bekehrung und von der Prädestination; Dieckhoff (1885), Der missourische Prädestinianismus und die Concordienformel; Scheibe (1897), Calvins Prädestinationslehre; Köstlin (1901), Luthers Theologie; Müller (1903), Die Bekenntnisschriften der reformierten Kirchen, s. v. Erwählung; Jacquin (1904), La question de La prédestination au Ve et Vle siècle in Revue de l'histoire ecclésiastique; van Oppenraaij (1906), La prédestination de l'église réformée des Pays-Bas.) A survey of the WorldCat database on books that are catalogued in (mostly) academic libraries around the world up to January 2016 shows that there are more than 7000 entries that deal with this idea. Yet, only recently scholars from non-theological fields have started to take a look of the possible influence of the notion of predestination in their own area of knowledge. Economists (Glaeser and Glendon 1998) have suggested that the differences of biblical interpretations about individual fate may be largely responsible for the way Protestant countries developed economically when compared to Catholic ones. Geographers have argued that the emergence of regional inequality within developing countries and of the emergence of giant urban centers are the result of conflict between 'predestination' and 'self-organizing' approaches to economic geography (Krugman 1999). In the field of psychology, Goodey (2001) has suggested that within the seventeenth century reformation movement in France, Calvinism and its notion of predestination was challenged by the belief that the mentally disable was free in his/her destiny from natural law.

In the natural sciences, the phrase 'biochemical predestination' was coined by Kenyon and Steinman (1969) and reiterated by de Duve (1995). Their basic argument was that since there are strict laws that govern physicochemical phenomena in nature, those very same laws must have made life an 'imperative' phenomenon beyond our earth. Therefore, the origin of life and its later evolution were irrepressible and we should expect to find life ubiquitous in the universe. These authors' explanations, confined to the biochemical realm, stop at the moment in which the 'RNA world' is formed and say nothing of organic evolution once the first organized beings (cells) appear.

In this paper I will argue that the notion of predestination has had a strong influence in the evolutionary ideas developed in the western world, particularly when it comes to explanations relative to the loss of phenotypic (morphological, behavioral, and physiological) features during evolution as epitomized by organisms living in caves and 
other light-deprived environments. I will further argue that such ideas have hampered and continue to hamper our understanding of the phenomenon of evolutionary loss of features.

My approach will be, first, to show how predestination has had very deep roots in all monotheistic religions since their inception. Then I will show how that idea was adopted -in some cases very explicitly- by evolutionary biologists as late as the Twentieth Century and continues to dominate the conversation when it comes with the explanation of some evolutionary processes, particularly in the realm of biospeleology. I will conclude by showing that we need to understand the influence of those ideas if we really want to assert the scientific process as one that is really objective and free of superfluous influences.

\section{Predestination in history}

\section{The 'Spanish Connection' of predestination and its influence in the western world}

Between the twelve and fifteen century, Spain lived through a unique convergence of ideas for a single country in Western Europe: Cristianos (Christians), Moros (Muslims), and Judíos (Jews) were all influencing Spanish thought not only religiously in the strictest sense but also in philosophy and literature.

We can find good examples of the preoccupation with predestination among Spanish writers such as Diego de Valencia (de Valencia 1984) a Franciscan monk and a marrano (originally a Jew), Ferran Sánchez Talavera or Calavera, Juan Alfonso de Baena a Calatravan monk and possibly a marrano, Fray Martin Alfonso de Cordoba an Augustinian monk and, particularly, Ausias March. March was the first major poet to write in Catalan and who would have a great influence on Romance poetry to this day. Of all his books Cant espiritual ('Spiritual song') is the one in which he expresses the confusion about the notion of predestination in pre-Renaissance Spain, probably as a result of the somewhat conflicting views generated by Christianity, Judaism, and Islam in that country. These writers provide an insight on the struggle of different views between free will and divine grace, between good and evil, and on the apparent incongruence of how God could create human beings predestine to damnation.

These views about predestination somehow expanded and became more universal due to three historical facts that took place in 1492:

1. The defeat of the moors in Spain imbedded a sense of fatalism in the psyche of Muslims setting the basis for rancor toward the western world that is still present today;

2. The expulsion of the Jews from Spain (or their forced conversion into Christianity), impregnating them with further messianic hopes and eschatology, furthering Kabbalism; 
3. and the notion that if Spain had been the one discovering America, it was because of predestination and that they had to take place their religious fervor under which both atrocities and humanitarian feats would be carried out (see Fuertes Herreros (1992), for more on the concept of predestination and the history of Spain). As we will see later, these concepts would be mirrored later on during the American Revolution all the way to the Romantic era as epitomized by the concept of 'manifest destiny.'

\section{Enter Double Predestination}

The new impetus and discussion on the issue of predestination in the sixteenth century comes by the hand of John Calvin. Calvin generated the concept of "double predestination" (Gemina Predestinatio) according to which God has actively chosen some people for damnation as well as for salvation confirming God as omniscient and omnipotent which is closely related to the doctrines of divine providence and grace. This is a contrasting view with the Catholic church (God wills the salvation of all souls but that certain souls are granted special grace that in effect foreordains their salvation, so the Roman Catholic Church teaches that predestination is consistent with free will).

Further discussion on how the concept of predestination continued to evolve can be found in Evans (1982), James III (1998) and Behringer (1999). In any case we can conclude that the idea of predestination was deeply rooted in all monotheistic religions and, therefore, we cannot be surprised that such a notion would spill over scientific ideas.

\section{Predestination and National Claims}

Although national pride has surfaced in many countries at many times, only two western countries can claim that the sense of being a predestined nation has become part of their psyche. They are the United States of America and France.

\section{The American Experience}

Unlike the colonization process that took place elsewhere in the American continent, the colonization of what is today the Unites States had little to do with the search of riches and rather had political and religious overtones. Ideologically speaking, the main actors were the Puritans. They were made up of an assortment of groups united by some common themes:

- an ideology of religious reformation that originated within the Church of England during the middle of the sixteenth century;

- their common Calvinist theology; and,

- the same critical stance toward the Anglican Church in particular and the English society and government in general. 
After their ascent to power in the person of Oliver Cromwell as a result of the English Civil War (1642-1651), their influence declined steadily as a result of the restoration of the Stuart monarchy in 1660. Because they were identified with radicalism and the autocratic Cromwell and his government, many moved to British North America (a phenomenon that actually started in the 1620 s as a result of religious intolerance in England), Scotland, and Northern Ireland. In North America they formed two main communities: The Congregationalists, settled in Massachusetts, Connecticut, and Rhode Island, and The Presbyterians, who settled mostly in New York, New Jersey, and Pennsylvania during the late seventeenth century and throughout the eighteenth century.

As the Pelagians and Semi-Pelagians, Puritans were concerned with what they considered social and moral corruption and developed a series of rules that governed many aspects of individual behavior, from dress codes to religious observances. As they continue to break away from the Church of England, they also wanted to make sure that there were no vestiges of rituals and practices that may resemble those of the Roman Catholic Church. Thus, their worship services were simple, austere, and centered on long, learned sermons in which their clergy expounded on passages from the Bible. The parishioners were expected to live an exemplary life dominated by temperance and restrain. They were possessed by a sense of predestination and that America was the Promised Land where they could act according to their own beliefs and with very little outside interference.

By the eighteenth century most of these conceptions of life had given away to a more competitive, individualistic, and secular society as a result of the growth in commercial capitalism and the intellectual challenges of the Age of Enlightening (Bushman 1967). Yet, many of their philosophical traits remained in place including the sense of predestination (Innes 1996).

The idea of predestination would resurface at least twice as a major component of the American social and political scene. One was during the American Revolution. Although the idea of religious predestination was severely criticized by Thomas Paine (see Paine 1854) politically speaking there is abundant literature that speaks for a development of a sense of national predestination. The next resurgence for the ideology of predestination will be seen during the era of American Romanticism in the mid 1800s when a sense of frontier, 'go west,' experimentation with new institutions, the idealization of NativeAmericans, and the integration of new immigrants (from Anglo-Saxon Europe other than from England) took place. James E. DeKay, for example, the author who first described a blind cave fish for the scientific literature, was strongly influenced by the American romantic authors of his time (Romero 2002). As we will see later, this context will help to explain why biospeleological ideas that espoused a sense of determinism became very popular among American researchers. 


\section{Biospeleological ideas in France and elsewhere in continental Europe}

There is a long history of the idea of predestination in France as a national ideology that includes emphasizing the teaching of nationalistic topics throughout the curriculum in schools (see, for example, http://www.napoleon-series.org/research/society/ c education.html). They have had a profound and lasting influence even in today's official policies to the extent that the government even subsidizes articles written in French by French scientists (See http://www.axl.cefan.ulaval.ca/europe/france-2politik francais.htm) and that country even has a cabinet-level position for the maintenance of the 'purity' of the French language. The Maintenance of the Purity of the French Language Act enacted in 1975 introduced fines for the use of banned Anglicisms. In 2006 the French subsidiary of General Electric Medical Systems was fined for more than 500,000 euros simply for issuing software manuals in English (see http://www.nytimes.com/2015/04/01/opinion/france-givesin-to-the-hashtag.html).

Within the scientific realm the lasting influence of the idea of predestination is quite apparent by French or French-based researchers on the intellectual influence on biological evolution in general and biospeleological ideas in particular to the point that their way of thinking and terminology has been pervasive in cave biology since Lamarck until the 1950s. To understand why this is so, we must (1) review the political and intellectual environment in France previous to the publication of Darwin's Origin in 1859; (2) examine how Darwin's book was received and investigate how and (3) why the French developed an evolutionary ideology of their own, particularly when it came to interpreting the nature of cave fauna.

Ideas on evolution (biological and otherwise) in pre-Origin France abound, but all have something in common: a strong philosophical rather than an empiric basis. Jean Baptiste Lamarck, a physician by training, considered himself a 'naturalist-philosopher', and therefore much of his narrative was shaped with speculations and metaphysics rather than facts. In addition, his evolutionary views (mostly expressed in his 1809 Philosophie Zoologique and the 1815 supplement to the Histoire naturelle) were never very well formulated and even sometimes contradictory. To make things worse, Lamarck's writings were translated into numerous languages, but such translations were not always accurate and some of his statements were reproduced out of context which contributed to the general confusion on to what Lamarck really said (). But one thing is for sure: he was an early organicist and progressionist who viewed nature as being linearly organized and saw today's organisms as the result of increasing complexity (). Lamarck was the main (although not the first) advocate of the idea of inheritance of acquired traits concept and of evolution as a goal-oriented process striving towards progressive complexity and perfection. In fact, he did not believe in the extinction of species but rather on the constant transformation into new ones.

He described a metaphysical 'power of life' (puissance de la nature) leading this process of increasing complexity. That, together with the modifying power of the environment was 
responsible for the life forms we see on earth. Although he never wrote about cave fauna, the case of parasites with simplified organization amused him; yet, he had a perfect explanation: they appeared primitive because they had been the recent product of spontaneous generation. External circumstances were responsible for deviations from the rule of progression and some contingency (e.g., the disuse of an organ) could alter the path to complexity generating lateral ramifications in his linear view of progression. For him the lack of teeth in whales and eyes in subterranean moles were perfect examples. Lamarck had a great influence on many scientists not only at his time but through the twentieth century. The progressionists ideas of Lamarck had also a great influence not only in Europe but in America as well where a vigorous neo-Lamarckian school developed. That school was following Lamarck's tenants with the exception of those that were more mystical in nature (Burkhardt 1977). Therefore, we can interpret that progressionism toward complexity as a form of predestination that all forms of live evolve as predestined by his mysterious "power of life."

Two Lamarck contemporaries would also make their own contributions to the notion of increasing complexity in nature. Jean Léopold Nicolas Frédéric (Georges) Cuvier, for example, although a creationist, noticed some 'progression' in the succession of the geologic record. Geoffroy Saint-Hillaire, was a believer in evolution, progressionism, and the Great Chain of Being, always looking for transitional forms (Bourdier 1972, Appel 1987). He discussed the issue of the origin of vestigial organs from a mystic/religious viewpoint and interpreted them as 'disgraces' of natural beauty. Saint-Hillaire, a protégé of Lamarck, was even less materialistic than his mentor and added an aura of mysticism to evolutionary ideas.

At the same time French philosophers were thinking along the same lines. For example, Marie-Jean-Antoine-Nicolas de Caritat, Marquis de Condorcet, a brilliant mathematician, philosopher, and political activist, infused the idea of progress into virtually all of his historical interpretations. He adopted the concept of inheritance of acquired characters in constructing his vision for the social and organic progressive improvement of humankind, an idea also espoused by other philosophers such as Herbert Spencer, Friedrich Engels, and Lester Ward (Condorcet 1802). These ideas strongly influenced the positivist school founded by the French philosopher Auguste Comte and the ideas of another French philosopher, Marcel de Serres. The latter proposed the view that life was a manifestation of progressive perfecting.

Thus, the intellectual environment in pre-Origin France was not anti-evolution as in other parts of Europe and the United States; actually one can say that no well-educated French person at that time harbored any predisposition against evolution (transformisme). In fact, in France, the idea of progression could be traced as far back as the development of Modern Science period (1650-1800) at the time of the Enlightenment and the French Encyclopedism. Lamarck contemporaries, with the exception of Cuvier, embraced some sort of transformism: although they were not sympathetic to (and even ridiculed to certain extent) Lamarck's unfounded speculations, particularly the idea that a new organ could be produced by the 'desire' of an organism to create it. However, the French were unprepared 
to view evolution as a materialistic, random process that excluded any metaphysical explanation. And the way Darwin's Origin was translated into French made matters worse.

The Origin was translated into French by Clémence-Augustine Royer. This polymath and feminist writer was not only a great believer in science, but also thought that women should transform it into 'female science.' Royer probably first heard of Darwin's new work on evolution through a review of The Origin by the Geneva-based Swiss entomologist and paleontologist Françoise Jules Pictet de la Rive while lecturing on Lamarck in Geneva in 1860. Pictet was one of the first to receive a copy of The Origin of Species directly from Darwin. As soon as Royer read The Origin, she convinced her publisher, Guillaumin, to print the first translation of Darwin's work into French. According to Royer, 'It was then [after lecturing in Geneva] that I translated the Origin of Species of Ch. Darwin, which had appeared in England, during the same winter in which I had affirmed in my course the doctrine of Lamarck. If I translated Darwin, it was because he had brought new proofs to the support of my thesis.' (Harvey 1999). In other words, her interest in translating Darwin was not so much to spread the Britton's gospel, but rather to prove how important Lamarck was as the father of evolution as an idea. And it showed.

With the advice of the French zoologist and early Darwinian enthusiast René-Edouard Claparède, who had also enthusiastically reviewed Darwin's book, she translated the third edition of The Origin (which was, in terms of explanations on rudimentation, more Lamarckian than the first two editions) adding not only numerous footnotes, but also a lengthy prologue in which she espoused eugenics, being probably the first author to do so by applying Darwin's ideas. Darwin, who had authorized to have his book translated into French, was not happy with Royer's preface and footnotes. She not only changed the title of the book, but more significantly, Royer used the word 'election' instead of 'selection' giving, thus, the impression that nature had a mind of its own directing on purpose evolutionary events.

The title of Darwin's book in French was De l'origine des espèces, ou Des lois de progrès chez les êtres organizes (The origin of species, or the laws of progress among organized beings) giving the impression that Darwin emphasized the idea of progress, a principle for which he was ambiguous at best. Darwin himself, in his correspondence to several of his colleagues such as Jean Louis Armand de Quatrefages, Charles Lyell, and Asa Gray, made it known that he was extremely unhappy with the French translation. Despite this version of The Origin being closer to the French state of mind, Darwin sensed that the book had a cold reception in France. In a letter to Quatrefages, a French naturalist who opposed Darwin's ideas on evolution but yet respected him, Darwin wrote, 'A week hardly passes without my hearing of some naturalist in Germany who supports my view, \& often puts an exaggerated value on my works; whilst in France I have not heard of a single zoologist except M. Gaudry [Albert Jean Gaudry] (and he only partially) who supports my views' (Darwin 1896). Darwin may have not been happy with this translation; yet, he might not have any other alternatives since he had trouble finding a publisher in France for his book anyway (Herbert 2005). 
For years to come, Royer continued publishing and lecturing about Lamarck, her personal hero. She, who was probably the first European woman recognized as a professional anthropologist, was also an enthusiastic caver.

Royer's translation of The Origin was very much celebrated by Étienne Rabaud. Rabaud had been a student of Alfred Girard, the first holder of the Chair of Evolution at the Sorbonne and a rabid Lamarckian. Rabaud became such a fanatical supporter of Lamarck's ideas that by the 1930's he even questioned the value of Darwinism (see, for example, Rabaud 1941). When commenting on Royer's preface, Rabaud was enthusiastic because she had restored Lamarck into public attention.

Were this improper translation and the current intellectual climate the only reasons for the poor reception of Darwin's ideas in France? Not really. Just before the publication of The Origin, France had witnessed one of the most public and passionate scientific controversies in history. Between 1858 and 1859 French society was inundated with the tales of the dispute between Félix Archimède Pouchet and Louis Pasteur, that is, between the belief in spontaneous generation and the belief that the ability to beget life is an exclusive and continual property of living beings. Although Pasteur won the argument and his was a triumph for science as a method of inquiry, Pouchet's sympathizers also supported agnosticism whereas Pasteur's were more comfortable with religious and metaphysical ideas. Thus, despite the fact that the French were not opposed to evolution as an idea per se, the mechanism championed by Darwin, natural selection, reminded them of the agnosticism and materialism attached to spontaneous generation. Thus, the land that had given birth to precursors of evolutionary ideas such as Georges-Louis Buffon, Lamarck, and Geoffroy Saint-Hillaire, gave Darwin a cold shoulder, and little public controversy of the book took place.

Other political and social events further cemented the French view of evolution as a mystical idea. One experience that generated a nationwide feeling of disgrace was the political and military humiliation of the French by the Prussians during the 1870-1871 War (Howard 1981). And as in any nation that has been defeated, their people found consolation in mystical nationalistic ideas. The ideas of national destiny and historical progress became strongly rooted in the French psyche and were reinforced through revisions of school curricula. The Spencerian interpretation of 'survival of the fittest' became very unpopular: Prussia had developed into an imperialistic and invincible neighbor and looked like 'the fittest' to French psyche. Now French intellectuals threw themselves fully into the arms of mysticism to explain their grand views of nature, and evolution was at the center of all this.

It was in this intellectual atmosphere that the seeds for French Neo-Lamarckism were planted, and these seeds were sown in abundance by French biospeleologists. The father of these neo-Lamarckian ideas in France was Henri Louis Bergson. Bergson was a philosopher and a mathematician whose ideas on evolution were largely anti-materialistic and sustained that organic evolution was just part of a larger, universal cosmic evolution. A Lamarckian follower regarding the canon of use and disuse and principle that evolution was directed by an internal force which he called élan vital. He was fiercely patriotic and 
opposed Darwinism because he did not accept the notion of an undirected mechanism such as natural selection as the major force of evolution. Part of his popularity was due to the fact that by using the notion of an élan vital, he was allowing for a role to be played by religion in evolutionary processes (Goudge 1973).

Bergson was familiar with the ideas of Cope and Theodor Gustav Heinrich Eimer, a disciple of Rudolf Albert Kölliker, who championed the idea of and popularized the term orthogenesis (Eimer 1888). The term orthogenesis was first proposed by the zoologist Johann Wilhelm Haacke (Haacke 1893). Others used different terms for essentially the same concept: orthoevolution (Plate 1913), nomogenesis (Berg 1926), aristogenesis (Osborn 1934), and the omega principle (de Chardin 1955). Bergson, an intense French patriot, proposed in 1907 the idea of theélan vital or vital impetus (the term is so obscure that it is usually left untranslated, but reminds that of Lamarck's expression of the 'power of life'). He used this term to refer to a characteristic of life that, according to him, always pushes life in the direction of complexity; that, for Bergson, was the mechanism of orthogenesis, which moved evolution from the domain of the divine into the natural world. Given that Bergson did not like natural selection as an idea because of its materialistic implications, and at the same time he could not find strong evidence supporting the inheritance of acquired characters, thus, élan vital was for him the answer. Of course, and unlike natural selection or the inheritance of acquired characters, since this idea could not be tested, it could not be disproved either.

According to Bergson, both Darwinian evolution and finalism (the idea that evolution has a sense of directedness toward an end and that such a path has already been laid) could coexist. And what is the unifying force behind such a possibility? It cannot be natural selection, of course, since that is based on apparent randomness, but rather it must be a mystical force, élan vital. These ideas may have been interpreted as Lamarckian with a religious twist, but that is also unclear: Bergson, a man profoundly concerned about the fate of his fellow Jews, almost became a catholic; it is evident therefore that his religious views were also complex. Bergson's ideas became extremely popular, and other philosophers such as the French Lucien Cuénot expanded them by arguing that species succeed in a particular environment because they were 'preadapted.' The term he coined waspréadaptation (Cuénot 1911), and it became an extremely popular idea among biospeleologists, many of whom still firmly believe in it today. Needless to say, Cuénot espoused linear evolution, only that in the new era of experimental genetics of early twentieth century, he believed that mutation (sensu stricto) was the cause of it.

In summary, Bergson was a progressionist but he did not believe that there was a necessarily pre-designed goal; rather that final progression would lead to a less predictable result trying, thus, to taint Darwinism with the very popular idea of progression.

All of these new philosophies of life were developed at the time when speleology in general and biospeleology in particular were becoming sciences in their own right, and all their foundations were being laid by French or France-based naturalists. Such was the case of the French lawyer Édouard-Alfred Martel. Martel was a lawyer and a geographer by training. He was known for his pioneer work in 1894 on the physiography and accessibility 
of caves, and he coined the term speleology (in both French and English) in the 1890s. He explored the limestone caves of Cévennes and, with others, made descents into previously unknown caves of Europe, Asia, and America. In 1895 he founded the Société de Spéléologie in France. Martel was the judge of the tribunal of commerce in Paris from 1886 until 1899, when he became a professor of subterranean geography at the Sorbonne (the first speleological academic post in the world); he was appointed a member of the staff of the Department of Geological Maps of France in 1901. He is often called 'the father of modern speleology' and his publication record includes more than 1,000 articles and books on the subject. In 1904 Armand Viré, another Frenchman, coined the term biospeleology ( biospeleologie). Viré had written his doctoral thesis on cave fauna in 1899 and thereafter established an underground laboratory in the catacombs of Paris.

However, the two figures that would ultimately consolidate biospeleology as a science and give it many of the distinctive features that it has today were Emil G. Racovitza and René Gabriel Jeannel. Racovitza, a Rumanian-born, French-educated naturalist, started exploring caves in the Pyrenees in 1905 together with his protégé Jeannel. Racovitza initiated an extensive international research program under the umbrella of Biospeologica (a supplement to the scientific French journal Archives de Zoologie Experimentale et Generale), primarily intending to document and collect cave fauna. In 1920 he founded in Cluj, Romania, the world's first speleological institute. He explored 1200 caves in Europe and Africa, collected about 50,000 specimens of cave animals, and published 66 papers on subterranean fauna totaling almost 6000 pages (Motas 1962). He read and was greatly influenced by, Eimer and Cope (on orthogenesis), Packard (on Neo-Lamarckism), and Louis Dollo (on general evolutionary ideas). He had a great deal of distaste for the selectionist Weisman (Motas 1962).

Rocovitza's two main publications dealing with biospeleological theory were his 1907 Essai sur les probleme Biospeologiques (Essays on biospeleological problems, published at the same time that Bergson was proposing his élan vital and considered to be the birth certificate of biospeleology as a science) and his little known 1929 Evolutia si problemele ei (Evolution and its problems) book. In those publications he clearly delineated his evolutionary thought about cave organisms, which can be summarized as follows:

1. all cave organisms were 'preadapted' to the cave environment;

2. function (or lack thereof) creates the organ (or generates its disappearance). He was a strong supported of the use vs. disuse concept;

3. natural selection is of little importance because natural variation is virtually nonexistent (he was a staunch typologist);

4. evolution is directional as evidenced by 'phyletic lines.'

Similar views were endorsed by his student Jeannel (Jeannel 1950) who studied subterranean beetles from Europe and Africa. With Racovitza he founded in 1907 the journal Biospeleologica and in 1926 published Faune cavernicole de la France. He considered many of the organisms found in caves as 'living fossils', and these ideas continue to have a tremendous impact on biospeleologists all over the world. 
Although all this can be presented as a great accomplishment for the French in terms of initiating and developing the systematic study of caves, none of these figures ever embraced any form of Darwinism, but rather different shades of Neo-Lamarckism first and different forms of finalism such as orthogenesis and organicism later. Thus, the French biologists who embraced transformism beginning in 1880 did so via Neo-Lamarckism while strongly opposing the idea of natural selection (Grimoult 1998). This philosophy extended well into the twentieth century with Lucien Cuénot, Maurice Caullery and Jean Rostand.

Therefore, the utilization of cave organisms as perfect examples for demonstrating the legitimacy of the French version of Neo-Lamarckism seemed to be inevitable, and this is exactly what happened. The main points in common of these French intellectuals were:

1. acceptance of evolution as a linear phenomenon (orthogenesis) leading to a perfecting complexity in nature;

2. rejection of natural selection as a phenomenon of any relevance;

3. development of finalism, vitalism, organicism, and other expressions of essentialism in biology;

4. utilization of cave organisms as 'perfect' examples of these views of life;

5. mutual reinforcement of ideas concerning biospeleological paradigms (blind, depigmented animals) and philosophical notions of progress within the same country: France.

These ideas were very much espoused by American biospeleologists who not only followed early directional and deterministic views of evolution (Romero 2009).

\section{The Jewish Tradition}

There is abundant pre-New Testament material such as select apocalypses[1] wisdom books, and the Qumran (Dead Sea scrolls) documents that attest for a sense of predestination in the understanding of life, destiny, and relationship with God. The firm belief on predestination of the Jewish faith would cool off from the deuteronomic (faithfulness to Yahweh and obedience to his commands bring blessings) approach to Israel's salvation to the spiritual wisdom (sapiential) tradition. This may have been as a response to persecution among Jews which may have compelled the wisdom teachers to adopt a new eschatological dualism, according to which salvation was ultimately determined not just on the basis of covenantal election, but also on the basis of fidelity to the law (Eskola 1998). Therefore, predestination although important, is not deterministic.

However, by the twelfth century, Judaism would turn into a more mystical conception of life through the Kabbala (Hebrew for tradition) with the publication of Sefer ha-bahir or 'Book of Brightness.' Kabbalism has its roots in first century Palestine and was a form of esoteric Jewish mysticism whose initiation into its doctrines and practices was conducted by a personal guide that included the knowledge of some 'secret wisdom' of the unwritten Torah that was communicated by God to Moses and Adam. Although observance to the law 
remained a pillar of Judaism, the Kabbala gave means to approach God directly and introduced the notion of transmigration of souls (gilgul).

However, the major influence on non-Judean thought in terms of predestination would come from two other works: Sefer ha-temuna or 'Book of the Image' and Sefer ha-zohar or 'Book of Splendor.' They deal with the notion of cosmic cycles and speculations about soul and salvation. They are important not only because they recapture in part the original ideas about predestination rooted in ancient Judaism but also because they were published in late Medieval Spain, a point we will return later.

\section{The Origins and Christian Tradition}

This notion of predestination has its roots in a number of pre-Christian religious documents whose prime example is the Qumran. There we can find the notion of predestination together with eschatological/apocalyptic concepts (Merrill 1975, Lange 1995). A passage that epitomizes these beliefs is:

In your wisdom you es[tablished] eternal [...]; before creating them you know all their deeds for ever and ever. [...] [Without you] nothing is done and nothing is known without your will" (García Martínez and Tigchelaar 1999).

The first Christian author to suggest the notion of predestination was Paul the Apostle. Originally a Jew and a fervent antichristian, he converted into the new religion shortly after the death of Jesus and went on to become one of the leading figures of early Christianity. He wrote:

For those whom he [God] foreknew he also predestined to be conformed to the image of his Son, in order that he might be the first-born among many brethren. And those whom he predestined he also called; and those whom he called he also justified; and those whom he justified he also glorified (Rom. 8:29-30).

However, the idea of predestination was not fully articulated until the writings of St. Augustine. His influence on Christian thought derives from both his synthesis of Platonism, Roman, and early Christian ideas that developed into a theological system that later made its mark on both Catholicism and Protestantism. St. Augustine's notion of predestination was that human beings could not attain righteousness by their own efforts and were totally dependent upon the grace of God. In other words, the actions of God were the ones that foreordain the future lot and fate of all mankind in this life and after death, including their salvation or perdition.

St. Augustine did not propose these ideas in an intellectual vacuum but was rather responding to the ideas of Pelagius. He and his followers stated that humans were essentially good and that their fate depended entirely on their will. Concerned about the lowering of moral standards among Christians, he hoped that by stressing personal responsibility their moral behavior would improve. St. Augustine attacked these ideas on 
philosophical grounds while the Christian church felt threatened largely because Pelagius and his followers rejected any claims of original sin by insisting that God created humans free to choose between good and evil, making sin an act of individual responsibility. Therefore, the baptism of the infant was unnecessary. This led to the labeling of Pelagianism as heresy and the excommunication of Pelagius and some of his followers.

Despite St. Augustine's theological attacks and the Church's political actions, the controversy was far from over. Others like Julian of Eclanum continued their support for Pelagianism despite the Church's threats and actions against them. At the end, a new ideology was developed. What was later called Semi-Pelagianism, can be defined as a movement that in some ways tried to reconcile both Pelagian and Augustinian thoughts. On one hand they agreed with St. Augustine that the original sin was a corruptive force among humans and that without God's grace this corruptive force could not be overcome, and they therefore agreed that Baptism of the infant was necessary; on the other hand, they agree with the Pelagians in that humans' will was very powerful. Therefore, they concluded, the innate corruption of humans was not too great as not to be overcome through the powers of individual determination.

The Semi-Pelagians were led by Johannes Cassian. He was an ascetic monk and theologian whose writings gave rise to the Western idea of monasticism as a result of his experiences in the hermits of Egypt. This influenced his beliefs on the importance of individual determination. Because in the final analysis Semi-Pelagians were asserting that there was no need for God's supernatural intervention for the empowering of man's will for saving action, their ideas were also considered heresy, but Cassian and his followers were not personally persecuted by the Church.

During Medieval Europe, the idea of predestination continued to be discussed by Christian theologians. Godescalc or Gottschalk of Orbais was a monk and theologian who believed that Christ's salvation was limited and that his power of redemption extended only to the elect, thus the elect went to eternal glory and the reprobate went to damnation. This was considered heresy and Godescalc was imprisoned.

The continuation of ideas of predestination would be carried well into Medieval Europe by Thomas Aquinas and, particularly, by Gregory of Rimini. For Aquinas, God wills the salvation of all souls although certain souls are granted special grace that in effect foreordains their salvation; thus, the damned are sent to hell only in the sense that God foresees their resistance to the grace given them. Gregory, on the other hand, believed that goodwill was insufficient to acquire the perfect love necessary for the vision of God to which Christians aspire. He reaffirmed the Church teachings on Baptism by stating that children dying without Baptism would suffer eternal punishment.

Peter Auriol a philosopher and critical thinker (he was a forerunner to William of Ockham) criticized St. Thomas Aquinas' theory of (scholastic) knowledge by emphasizing the part played by experience in knowledge against that played by reasoning. He wrote on predestination in Commentariorum in primum librum sententiarum, Tractatus de paupertate , Tractatus de principiis naturae, and Tractatus de conceptione beatae Mariae Virginis and 
proposed that God offers his grace freely to all human beings; therefore, salvation comes to those who passively accept this free offer of grace.

\section{Conclusions}

Since the advent of Modern Synthesis we have a pretty consistent set of evidence that evolution is not linear, that there is not such a thing as direction for evolutionary processes, and that nothing is predetermined since natural selection, the main evolutionary mechanism, is a process that is not moved by any mystical force nor directs beings toward a particular end. Yet, biospeleologists continue seeing "preadaptations" and "regressive evolution" (which implies direction) anywhere when it comes to cave fauna (Romero 1985, Romero and Green 2005). Therefore, this paper demonstrates that the imprint of the idea of predestination still casts a shadow in modern evolutionary biology. I am not saying that modern biospeleologists do science under some sort of religious fervor but what many of them seem to neglect is that words matter and that words can hide a lot of the philosophical baggage that sooner or later may influence their ultimate conclusion.

Therefore, I hope this paper serves as a warning to scientists that no matter what reductionist view they have in the way they practice their research, if they do not understand the historical roots and the philosophical framework of their research they are doomed at presenting only a very partial (and many times biased) view of nature.

\section{Additional References}

- Archer, R. 1993. Ausias March and the Baena debate on predestination. Medium Aevum 62:35-50.

- $\quad$ Baker, K.M. 2004. On Condorcet's “sketch”. Daedalus 133:56-64.

- Berry, S. 1997. "Biochemical predestination" as Heuristic principle for understanding the origin of life. Journal of Chemical Education 74:950-951.

- Bockmuehl, M. 1998. Wisdom and predestination: Sapiential themes and predestination in the 'Dead Sea Scrolls' of Qumran by A. Lange. Vetus Testamemtum 48:126-127.

- Bonnet, C. 1770. Palingenesie philosophique, ou idees sur l'etat passé et sur l'etat future des etres vivans. Genève: C. Philibert et $\mathrm{B}$. Chirol.

- Brooks, E.S. 1992. Rrhyme, reason, and absence in Calavera, Ferran, Sanchez debate on predestination. Romance Notes 33:161-168.

- Buffon. 1954. Oeuvres philosophiques de Buffon. Paris: Jean Piveteau.

- Cameron, E. 2001. Peter Martyr Vermigli and predestination. The Augustinian inheritance of an Italian reformer by F.A. James. American Historical Review 106:675-676.

- Churchill, F.B. 1990. Eimer, Theodore Gustav Heinrich, pp. 261-264, In: C. Gillispie (ed). Dictionary of Scientific Biography, Suppl. 2, Vol. 17. New York: Charles Scribner's Sons. 
- $\quad$ Clarke, F.S. 1976. Lost and found - Athanasius' doctrine of predestination. Scottish Journal of Theology 29:435-450.

- Cohen-Mohr, D. 2001. A matter of fate: The concept of fate in the Arab world as reflected in modern Arabic literature. Oxford, UK: Oxford University Press.

- Coleman, W. 1964. Georges Cuvier, Zoologist: a study in the history of evolution theory. Cambridge: Harvard University Press.

- Collins, J.J. 1997. Wisdom and predestination: Elemental traces of wisdom and prophecy from the Qumran corpus, A. Lange. Journal of Religion 77:283-285.

- Corsi, P. 2005. Before Darwin: transformist concepts in European natural history. Journal of the History of Biology 38:67-83.

- $\quad$ Delcor, M. 1976. Merrill, E.H. Qumran and predestination. Biblica 57:257-258.

- Desmazières de Séchelles, R. 1967. Essai sur la prédestination de la France. Paris: Fischbacher.

- Eddy, J.H. 1994. Buffon's Histoire naturelle. History? A critique of recent interpretations. Isis 85:644-661.

- Farber, P.L. 1975. Buffon and Daubenton: divergent traditions within the Histoire naturelle. Isis 66:63-74.

- $\quad$ Flint, R. 1988. Predestination. Triquarterly (73):129-130. (Poetry).

- Ginther, J. 2002. Peter Martyr Vermigli and predestination: The Augustinian inheritance of an Italian reformer by F.A. James. Speculum. A Journal of Medieval Studies 77:196-197.

- Grassie, W. 1997. Postmodernism: What One Needs to Know, Zygon: Journal of Religion and Science 32:83-94.

- Granger, G. 1971. Condorcet, Marie-Jean-Antoine-Nicolas, Marquis de, pp. 383-399, In: C.C. Gillispie (Ed.). Dictionary of Scientific Biography, Vol. 3. New York: Scribner.

- Halverson, J.L. 1998. Peter Aureol on predestination: A challenge to late medieval thought. Leiden: Brill.

- Hazlett, W.I.P. 2000. Peter Martyr Vermigli and predestination. The Augustinian inheritance of an Italian reformer by F.A. James. Journal of Ecclesiastical History 51:626-627.

- Hill, P. 2001. Fate, predestination and human action in the Mahabharat: a study in the history of ideas. New Delhi: Munshiram Manoharlal Publishers.

- Hintzsche, E. 1973. Koellikeer, Rudolf Albert von, pp. 437-440, In: C.C. Gillispie (Ed.). Dictionary of Scientific Biography, Vol. 7. New York: Scribner.

- Jenson, G.R. 1983. The problem of determinism: with reference to the Qumran Scrolls \& the First Epistle of John. Calimesa, CA: The Author.

- Kingdon, R.M. 2000. Peter Martyr Vermigli and predestination: The Augustinian inheritance of an Italian reformer by F.A. James. Church History 69:187-188.

- Kraege, J.D. 1998. Fresh look at the doctrine of predestination. Etudes Theologiques et Rreligieuses 73:349-369.

- Kugler, R.A. 1998. 'Wisdom' and predestination: Sapiential primeval order and predestination in Qumranic sources by A. Lange. Journal of Biblical Literature 117:735-736. 
- $\quad$ Leith, J.A. 1989. L'Evolution de l'idee de progres a travers l'histoire. Transactions of the Royal Society of Canada 4:3-8.

- $\quad$ Louise, E. 1980. On predestination. Obsidian-black Literature in Review 6:169-169. (Poetry).

- Macaghobhainn, I. 1977. 'Predestination' Poetry Australia (63):91-91.

- Mayr, E. 1982. The Growth of Biological Thought: Diversity, Evolution, and Inheritance. Cambridge: Belknap Press.

- Meier, F. 1981. Predestination and the doctrines of Ibn-Taimiyya. Saeculum Ann 32:74-89.

- Maury, P. 1960. Predestination, and other papers. London: SCM Press.

- Moreno, A.G. Castilian tracts on predestination, the Trinity and the incarnation from Diego de Valencia, 15th-century, a critical edition. Romance Philology 41:117-120.

- Prince, J.S. 1997. Possible sources of ambiguity in Robert Herrick's "Predestination" sequence. English Language Notes 35:16-22.

- Rainbow, J.H. 1990. The will of God and the cross: an historical and theological study of John Calvin's doctrine of limited redemption. Allison Park, Pa.: Pickwick Publications.

- Robson, M. 1999. Peter Aureol on predestination. A challenge to late medieval thought by J.L. Halverson. Revue D'Histoire Ecclesiastique. 94:953-956.

- Roger, J. 1973. Buffon, Georges-Louis Leclerc, Compte de, pp. 576-582, In: C.C. Gilliespie (Ed.). Dictionary of Scientific Biography, Vol. 2. New York: Scribner.

- Roger, J. 1997. Buffon. A life in natural history. Ithaca: Cornell University Press.

- $\quad$ Sloan, P.R. 1976. The Buffon-Linnaeus controversy. Isis 67:356-375.

- Tétry, A. 1971a. Caullery, Maurice, pp. 148-149, In: C.C. Gillispie (Ed.). Dictionary of Scientific Biography, Vol. 3. New York: Scribner.

- Thompson, J.L. 2000. Peter Martyr Vermigli and predestination: The Augustinian inheritance of an Italian reformer by F.A. James. Sixteenth Century Journal 31:509-511.

- Vajda, G. 1976. Between Hadith and theology - origins of tradition of predestination. Revue de l'Histoire des Religions 189:105-107.

- van Ess, J. 1975. Zwischen Hadit und Theologie: Studien zum Entstehen prädestinatianischer Überlieferung. Berlin: New York: De Gruyter.

- Watt, W.M. 1948. Free will and predestination in early Islam. London: Luzac.

- Weiss, J. 1987. Spanish treatises on predestination and on the trinity and the incarnation by Diego de Valencia - an identification of his authorship and a critical edition. Bulletin of Hispanic Studies 64:145-146.

- Wensinck, A.J. 1932. The Muslim creed: Its genesis and historical development. London: Frank Cass.

- Wilson, L.G. 1973. Lyell, Charles, pp. 563-577, In: C.C. Gillispie (Ed.). Dictionary of Scientific Biography, Vol. 8. New York: Scribner.

- Wright, D.F. 2000. Peter Martyr Vermigli and predestination. The Augustinian inheritance of an Italian reformer by F.A. James. Journal of Theological Studies 51:374-377 


\section{Acknowledgements}

The idea of exploring the influence of of predestination in science originated in a conversation on this topic I had with Phil Regan. I thank Brian J. O'Neill who read an earlier version of this paper and made valuable suggestions.

\section{References}

- $\quad$ Appel TA (1987) The Cuvier-Geoffroy debate: French biology in the decades before Darwin. Oxford University Press, 306 pp.

- Behringer W (1999) Climatic change and witch-hunting: The impact of the Little Ice Age on mentalities. Climatic Change 43: 335-351. DOI: 10.1007/978-94-015-9259-8 13

- Berg LS (1926) Nomogenesis; or, evolution determined by law. Constable, London, 477 pp.

- Bourdier F (1972) Geoffroy Saint-Hilaire, Ėtienne. In: Gilliespie CC (Ed.) Dictionary of Scientific Biography. 5. Scribner, New York.

- $\quad$ Burkhardt RW (1977) The Spirit of System. Harvard University Press, Cambridge, 320

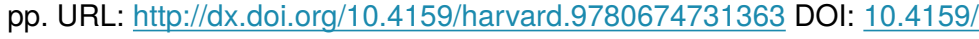
harvard.9780674731363

- $\quad$ Bushman R (1967) From Puritan to Yankee: character and the social order in Connecticut, 1690-1765. Harvard University Press., Cambridge, 343 pp.

- Condorcet J-NdC (1802) Outlines of an historical view of the progress of the human mind being a posthumous work of the late M. de Condorcet. G. Fryer, for J. Frank, Baltimore, $398 \mathrm{pp}$.

- Cuénot L (1911) La genesis de las especes animals. Librairie Félix Alcan, Paris, 284 pp.

- Darwin F (1896) The life and letters of Charles Darwin. D. Appleton and Company, New York, $576 \mathrm{pp}$.

- $\quad$ de Chardin T (1955) Le phénomè humain. Du Seuill, Paris, 318 pp.

- de Duve C (1995) Vital dust: life as a cosmic imperative. Basic Books, New York, 362 pp.

- $\quad$ de Valencia D (1984) Isaac Vazquez Janeiro, Tratados castellanos sobre la predestinación y sobre la Trinidad y la Encarnación, del Maestro Fray Diego de Valencia OFM (siglo XV). Identificación de su autoría y edición crítica (coll. Bibliotheca Theologica Hispana - Textos, 2). Consejo Superior de Investigaciones Científicas, Madrid, $184 \mathrm{pp}$.

- $\quad$ Eimer T (1888) Die Entstehung der Arten auf Grund von Vererben erworbener Eigenschaften nach den Gesetzen organischen Waschsens. G. Fischer, Jena, 435 pp. DOI: $10.5962 /$ bhl.title. 1350

- Eskola T (1998) Theodicy and Predestination in Pauline Soteriology. Mohr-Siebeck, Tübingen, $353 \mathrm{pp}$.

- $\quad$ Evans GR (1982) The grammar of predestination in the $9^{\text {th }}$ century. Journal of Theological Studies 33: 134-145. DOI: 10.1093/jts/XXXIII.1.134

- $\quad$ Fuertes Herreros JL (1992) Knowledge, fortune and predestination concerning the discovery of America. Arbor: Ciencia, Pensamiento y Cultura 143: 133-160. 
- García Martínez F, Tigchelaar EJ (1999) The Dead Sea Scrolls. Study Edition. Brill, Leiden, 1389 pp.

- $\quad$ Glaeser EL, Glendon S (1998) Incentives, predestination and free will. Economic Inquiry 36: 429-443. DOI: 10.1111/j.1465-7295.1998.tb01724.x

- Goodey CF (2001) From natural disability to the moral man: Calvinism and the history of psychology. History of the Human Sciences 14: 1-29. DOI: $\underline{10.1177 / 0952695012212098}$ $\underline{9}$

- $\quad$ Grimoult C (1998) Évolutionnisme et fixisme en France. Histoire d'un combat 1800-1882. CNRS Éditions, Paris, 184 pp.

- Haacke W (1893) Gestaltung und Vererbung. Eine Entwicklungsmechanik des Organismus. Verlag, T.O. Weigel, Leipzig, $312 \mathrm{pp}$.

- Harvey J (1999) A Focal Point for Feminism, Politics, and Science in France: The Clémence Royer Centennial Celebration of 1930. Osiris 14: 86-101. DOI: $10.1086 / 6493$ 01

- Herbert S (2005) The Darwinian revolution revisited. Journal of the History of Biology 38: 51-66. DOI: 10.1007/s10739-004-6509-y

- Howard M (1981) The Franco-Prussian War: The German invasion of France, 1870-1871. Routledge, London, $536 \mathrm{pp}$.

- Innes S (1996) Creating the Commonwealth: the economic culture of Puritan New England. W.W. Norton \& Company, New York, 416 pp.

- James III FA (1998) Peter Martyr Vermigli and predestination. Clarendon Press, Oxford, $304 \mathrm{pp}$.

- Jeannel RG (1950) La marche de l'evolution. Presses universitaires de France, Paris, $171 \mathrm{pp}$.

- Kenyon DH, Steinman G (1969) Biochemical Predestination. McGraw-Hill, New York, $301 \mathrm{pp}$.

- Kincaid H, Dupré J, Wylie A (2007) Value-Free Science? Oxford University Press, Oxford, 239 pp. URL: http://dx.doi.org/10.1093/acprof:oso/9780195308969.001.0001 DOI: 10.1093/acprof:oso/9780195308969.001.0001

- Krugman P (1999) The role of geography in development. International Regional Science Review 22: 142-161. DOI: $10.1177 / 016001799761012307$

- $\quad$ Lange A (1995) Weisheit und Prädestination: Weisheitliche Urordnung und Prädestination in den Textfunden von Qumran. E.J. Brill, New York, 345 pp.

- Merrill EH (1975) Qumran and predestination: A theological study of the thanksgiving hymns. Brill, Leiden, $71 \mathrm{pp}$.

- Motas C (1962) Emil G. Racovitza: Founder of biospeleology. National Speleological Society Bulletin 24: 3-8.

- Osborn HF (1934) Aristogenesis, the creative principle in the origin of species. Pamphlet, New York, 9 pp.

- Paine T (1854) Thomas Paine Addresses Calvinist Clergy on Predestination. http:// www.deism.com/paine essay predestination calvinism.htm. Accession date: 20161 05.

- $\quad$ Plate L (1913) Selektionsprinzip und Probleme der Artbildung. Ein Handbuch des Darwinismus. Verlag von Wilhelm Engelmann, Leipzig und Berlin, 650 pp.

- Rabaud E (1941) Introduction aux sciences biologiques. Armand Colin, Paris, 214 pp.

- Romero A (1985) Can evolution regress? National Speleological Society Bulletin 47: 86-88. 
- Romero A (2002) Between the first blind cave fish and the last of the Mohicans: the scientific romanticism of James E. DeKay. Journal of Spelean History 36: 19-29.

- Romero A (2009) Cave biology: life in darkness. Cambridge University Press, Cambridge, 306 pp. DOI: 10.1017/CBO9780511596841

- $\quad$ Romero A, Green SM (2005) The end of regressive evolution: examining andinterpreting the evidence from cave fishes. Journal of Fish Biology 67: 3-32. DOI: 1 0.1111/j.0022-1112.2005.00776.x 